\title{
Spinoza, Emerson, and Peirce: Re-Thinking the Genealogy of Pragmatism
}

\section{Presidential Address}

ROSSELLA FABBRICHESI ${ }^{1}$

\begin{abstract}
Pragmatism is not a doctrine: it is a method that makes our own ideas clear. Yet, the object of any idea is not properly an 'object' in the traditional sense. The object of any conception is something related to a power, a capacity, a preparedness to act and produce effects. The definition of meaning is not - particularly in Peirce's thinking - something well-profiled, a clear-edged form which is precisely and perfectly said. It is rather designed by the unlimited tension of its capacity to generate consequences, or - to put it in synechistic terms - by the continuous, growing and unpredictable development of "would-bes" and "would-acts."

Thus, the definition of an idea, or a belief, cannot be a precise response to the question: "What is it?" - rather, it is the answer to the question "What could it do?". It doesn't address an indicative form, but a conditional power.

My thesis is that this view marks a profound revolution in our tradition of thought, a revolution that in modern times has been prepared by Spinoza (who interpreted in his Ethics the essence of any being not as pure form, but as power and potentia agendi). Peirce showed, especially from 1890 on, to know very well Spinoza's thought. We have a remarkable review for The nation (1904) in which he related Spinoza to pragmatism, because for him "the substance of what one believes does not consist in any mere sensuous representation, but in how one would be disposed to behave."

Through Emerson's mediation (a Spinozian-Schellinghian thinker, incredibly influential in the Cambridge atmosphere), through his re-definition of the notion of 'power' and 'endeavor,' this Spinozian-Emersonian tradition acted like a virus: hidden in the folds of Peirce's reflections, it permanently affected their marrow.
\end{abstract}

Keywords:

Spinoza, Emerson, Peirce, Pragmatism, Power, Would-be, Preparedness to Act.

It is not always easy to explain what it means to think in a pragmatist way. Is it simply a way of looking at practical, everyday life matters from a philosophical standpoint? Is it a way of thinking that belongs to a precise theoric movement, as lofty and profound as, for example, the phenomenological or neo-positivistic ones? What distinguishes the pragmatist way of philosophizing? James addresses this question by clarifying that pragmatism is not a doctrine, but an attitude, a tendency to reason in a certain way. Peirce characterizes it as a method to make our ideas clear and produce stable beliefs. According to pragmatists, the meaning of any conception should not be treated as an abstract notion. It should be based on the differences it would produce in our practice, were we to believe it to be true - whence the tendency to emphasize the value not 
of causes or principles, but of effects and results, and to regard ideas less as universals of reason than as plans for action.

Some scholars have linked this tendency to the influence of English empiricism. Yet, pragmatism also owes something to the Nicomachean Ethics, to a naturalistic version of Hegelism, and to the great influence of Kantism, especially on Peirce - not to mention Evolutionism. In my view, though, one cannot entirely explain the underlying idea of pragmatism by reference to these influences alone. It is something more than, and utterly original compared to, these wellestablished traditions. Peirce himself outlines a different genealogy:

I may mention, for the benefit of those who are curious in studying mental biographies, that I was born and reared in the neighborhood of Concord - I mean in Cambridge - at the time when Emerson, Hedge, and their friends were disseminating the ideas that they had caught from Schelling, and Schelling from Plotinus, from Boehm, or from God knows what minds stricken with the monstrous mysticism of the East. But the atmosphere of Cambridge held many an antiseptic against Concord transcendentalism; and I am not conscious of having contracted any of that virus. Nevertheless, it is probable that some cultured bacilli, some benignant form of the disease was implanted in my soul, and that now, after long incubation, it comes to the surface, modified by mathematical conceptions and by training in physical investigations. (W8: 135, The Law of Mind.) ${ }^{2}$

I will try to take Peirce's transcendentalist and Schellingian genealogy seriously. While I follow a specific historiographical path, I shall also proceed in light of a more general theory of hermeneutical inspiration. Let us bear in mind what Peirce had already expressed in 1868, in a seemingly marginal note of Some Consequences of Four Incapacities: "Accordingly, just as we say that a body is in motion, and not that motion is in a body, we ought to say that we are in thought and not that thoughts are in us" (W2:227n4.) In what kind of common thought do we - who call ourselves pragmatists - find ourselves, in what current do we "swim," to borrow a word from Peirce's theory of synechism? Whence does the idea originate according to which meanings are to be clarified by what they enable us to do?

To answer this question and present my hypothesis as precisely as possible, I will begin by recalling a particular event from Peirce's life. Ralph Waldo Emerson held a series of lectures at Harvard College, Cambridge, in 1870-71. ${ }^{3}$ These served as the basis for one of his last contributions, "The Natural History of Intellect". The young Peirce was one of the seven invited lecturers and followed Emerson's lectures with great interest. Emerson was a mature man; he had already written both Essays and The Conduct of Life; by all accounts, he had a tremendous appeal on those who attended his lectures. Peirce was very impressed by "The Natural History". One could say he was truly infected by the ideas which Emerson disseminated as 'germs' in the Bostonian atmosphere - metaphysical, speculative and, at the same time, genuinely naturalistic and proto-pragmatist ideas. Certainly, Peirce harmonized them with different interests of his: logic, mathematics, the theory of inquiry and the study of categories. But Emerson's ideas never faded away from Peirce's search. To the contrary, they developed into its cornerstone, as I will show in a moment. ${ }^{4}$

Let me make another introductory remark. Peirce articulated a conceptual architecture which is unparalleled in the contemporary world. His philosophical method is not designed as a purely formal one, but precisely as a meth-odos - a way (odos, in Greek) - leading to ethical and metaphysical objectives through the tools of the logic of research. As is known to anyone who has 
ever approached Peirce's work, in his system tout se tiens: Peirce's theory of categories is a framework for understanding both cosmology and the logic of relatives; semiotics is not only linguistic theory but also a key to interpret, for example, theology; metaphysics is supported by a pragmatic vision; mathematics comprises questions of generality and vagueness; logic aims at a complete regeneration of the traditional way of reasoning and must result in a diagrammatic project of new scripture, and so on and so forth. But if it is true that, in Peirce, everything is held together, this happens by virtue of a specific element: as he himself points out, synechism - in its close relation to fallibilism, realism and infinite semiosis - is "the master key which adepts tell us unlocks the arcana of philosophy" (CP 1.163.) Those who focus their attention only on one aspect of Peirce's thought do not and cannot comprehend it; his aim was unequivocally to express the growth of concrete reasonableness in different fields, a principle that is metaphysical as well as empiricist and pragmatist.

Synechism represents the law of continuity connecting everything that is present in the universe, be it ideal or real (including the very distinction between ideal and real). It implies the absence of any division or break between one entity and another, and the impossibility of accurately evaluating the individuality of things. "For where there is continuity the exact ascertainment of real quantities is too obviously impossible" (CP 1.172.) There cannot be autonomous parts, "unrelated chunks of being" (EP2: 2); we must avoid reasoning by referring to pure substances, res; we should rather proceed by focusing our attention on the merging of parts into each other. First of all, therefore, there can be no dualism between mind and matter, thought and reality, man and the world.

But this Spinozian-Schellingian principle should be read from an evolutionary and pragmatist perspective. We need to reach the idea that everything endlessly develops and improves its results. No result is stationary (CP 1.614), and this leads to think:

The essence of Reason is such that its being never can have been completely perfected. It always must be in a state of incipiency, of growth. It is like the character of a man which consists in the ideas that he will conceive and in the efforts that he will make, and which only develops as the occasion actually arise. Yet in all his life long no son of Adam has ever fully manifested what there was in him. So then, the development of Reason requires as a part of it the occurrence of more individual events than ever can occur. (CP 1.615, emphasis added.) ${ }^{5}$

Peirce here very clearly shows what he means by "the development of concrete reasonableness."6

What he means leads directly to my argument: if it is true that being is continuously "in the making", that any possible definition of a human being, or entity, changes along the way, we can say that Peirce does not think of essence as static, formal and substantial, but views it as a power of development and a train of conceivable actions. Reason and Being are in a state of incipiency, of growth, as we have read (the influence of Darwinian evolutionism is evident here. ${ }^{7}$ ) But this means that being is to be defined by its consequences and, in the case of man, also by the efforts he puts into effect to achieve his objectives. Yet, "no agglomerations of actual happenings can ever completely fill up the meaning of a "would be" (EP2:402). Continuity is "something whose possibilities of determination no multitude of individuals can exhaust" (CP 6.170).

In this way, Peirce marks the extreme originality of his pragmatist thinking and its radical difference from any other twentieth-century tradition. Pragmatism is an attitude to understand each being in light of the question "What can it do?" - not "What is it?". Take Peirce's example of the diamond (used from 1878, cf. W1:132, to 1905, EP2:356): if subjected to pressure, every diamond 
resists, thereby manifesting its power (not essence or form) to be hard, its power to resist in all possible circumstances - predictably, but also absolutely unpredictably. And no definition of a diamond could be more precise.

At the same time, we must dismiss the idea that the occult state of things (be it a relation among atoms or something else), which constitutes the reality of a diamond's hardness can possibly consist in anything but in the truth of a general conditional proposition. For to what else does the entire teaching of chemistry relate except to the "behavior" of different possible kinds of material substance? And in what does that behavior consist except that if a substance of a certain kind should be exposed to an agency of a certain kind, a certain kind of sensible result would ensue, according to our experiences hitherto. As for the pragmaticist, it is precisely his position that nothing else than this can be so much as meant by saying that an object possesses a character. He is therefore obliged to subscribe to the doctrine of a real Modality, including real Necessity and real Possibility. (EP2:357, Issues of Pragmaticism, 1906)

The most perfect definition of the meaning of a word (for example, the word "hard") is the description of the habits it leads us to adopt and the effects it is capable of producing. But such a description will never be complete. It is simply the indication of a power: a "preparedness to act" (cf. EP2:399. $)^{8}$ Its repeated confirmation will always be conditional upon the realization of further states and events.

The method to "make our ideas clear", therefore, does not lead to the outlining of clear-cut and well-defined meanings, established once and for all. A clear idea is not the substantial eidos of Aristotle, nor a concept which analytically falls within the order of a dictionary (Eco 1984: 84-5); rather, it is something that takes shape by reference to practical examples that might derive from its use in broad semiotic contexts. Peirce develops his argument on the basis of the notions of power, disposition, and resolution to act: something which, by definition, knows no perimeters, boundaries or fixed limits, but which is rather defined by the unlimited tension of its capacity to produce effects, or - to put it in synechistic terms - by the continuous, growing and unpredictable development of "would-be" and "would-act" (EP2: 402).

In the light of this, I believe that Peirce's real teacher is precisely Emerson. It can be easily demonstrated that, in Emerson, the notion of power is quite fundamental (a fact Nietzsche had grasped very well ${ }^{9}$ ). One of the most important essays in The Conduct of Life (Emerson 1904: Vol.VI, Ch.II) is entitled "Power."10 Life "is a search after power" (II:1), we read at the beginning of the essay, and its forms and manners are but modes of power. The real question is thus" Not what, but how" ("Behavior", Vol. VI, Ch.V: 1): "The power of manners is incessant" (ibid.), "and every gesture and action shall indicate power at rest." (ibid, V:34) However, in Emerson's work the reference to vital power is inextricably linked to an acknowledgement of the force exerted by the laws of Nature, which are our own laws (see "Nature"). Likewise, as we have seen, for Peirce pragmatism and synechism go hand in hand: to see the core of each concept in the productive power of the inexhaustible series of sensible effects deriving from its comprehension is to envisage a continuity between mind and matter, between the intellectual and the sensible.

All power is of one kind, a sharing of the nature of the world. The mind that is parallel with the laws of nature will be in the current of events, and strong with their strength. One man is made of the same stuff of which events are made; it is 
sympathy with the course of things; can predict it. (Emerson 1904; Vol. VI, Ch.II: 5, "Power")

It is Emerson's insistence on the notion of self-reliance, a guiding idea of his research, that shows how fundamental to his thought the idea of power really is. As Cornel West points out (West 1989), this idea lies at the origin of the 'anthropological mythology' of the American man, the man resistant to adversity, connected to the beautiful nature around him, ready to conquer the border, but also ideally to overcome any inner border; the ideal of becoming what you think you deserve to be, so as to rightfully boast about your rights. But, upon a closer reading of Emerson's work, it is clear that self-reliance is nothing but confidence in the simultaneity between the expression of one's thoughts and the forces of nature, the awareness of being perfect at every moment of every event, the strength to understand that good and evil are only forms in which one expresses satisfaction or dissatisfaction at one's own power to act (cf. Emerson 1904: Vol.2, Essays, 1st Series. Ch.II: "Self-Reliance"), the law of one's own nature. This is anything but individualism; rather, it is a form of naturalism that boils down to a Spinozian resolution: man is not a special domain within nature, and nothing in it gives him reason for self-commiseration (see Ethics, Part III, "Preface") - "to the poet, to the philosopher, to the saint, all things are friendly and sacred, all events profitable, all days holy, all men divine" (Emerson 1904: Vol.2, Ch. 1:12, "History").

This affirmative and synechistic vision is based on the equivalence between nature and power: "the genius of man is a continuation of the power that made him" (Emerson 1904: Vol. XII: Ch.1:99, "The Natural History of Intellect"). "An individual mind is a fixation or momentary eddy in which certain services and powers are taken up and minister in petty niches and localities, and then, being released, return to the unbounded soul of the world" (ibid.:65). Man-world continuity expresses itself in constant acts of power: "Each man is a new power in Nature" (ibid.: 67). "a constructive power" (109). And again, "Nothing is secure but life, transition, the energizing spirit" (Emerson 1904: Vol.2, Ch.X:29, Essays 1st Series. "Circles"). Step by step we scale his mysterious ladder; "the steps are actions, the new prospect is power". (ibid.:7). The character itself is read as power, that must characterize the good social structure, too ("the energetic class.") 11

But normally - writes Dilworth (Dilworth 2010: 40,) discussing some of these passages - we are alienated from ourselves, not trusting the unknown powers of our own thought. Self-reliance means trusting this very power and derive joy and happiness from that. The strength of perseverance converges with that of power: "There is but one liberator in this life from the demons that invade us, and that is Endeavour - earnest, entire, perennial endeavour" (Emerson 1904: Vol. XII, Ch.2: 27, "The Natural History of Intellect: Instinct and Inspiration", and see the remarks in Dilworth 2010: 41.) How can we not think here of the Spinozian conatus? Emerson rarely mentions Spinoza. ${ }^{12}$ But let us not forget that Spinoza had long been banned from the academic and scientific arena; he was, after all, the heretical philosopher par excellence. Although immensely influential for Goethe, Schelling and most Romantics (all pivotal authors for Emerson), his name created a sort of embarrassment in religiously inspired circles.

Yet, I would like to show how the ideas just outlined, which point to some of the principal themes in Emersonian philosophical thought, are of fully Spinozian inspiration.

I will not base my remarks on the first two books of Spinoza's Ethics - where the metaphysics of substance, attributes and modes are traced - but on the third and fourth books. These are the parts Gilles Deleuze has brought back to contemporary attention, basing his interpretation specifically on the notion of power. ${ }^{13}$ Let us briefly recall a few points that may be helpful to clarify my argument. God, the sole Substance or Nature, expresses himself in infinite ways thanks to his infinite power to act. The power of God, therefore, his potentia agendi, wholly marks his 
substantiality (his "active essence", writes Spinoza in Ethics I, P34.) Spinoza offers us the idea of an operational deity, always at work, active and efficient, expressing an event by each of his actions, without ever ceasing to produce pragmatically relevant, "useful" effects (not merely "good" effects, but rather ones that are good because they are useful.) ${ }^{14}$ Every reality proves perfect as it is, since it is nothing but a way in which God presents himself (herein lies the all too apparent heresy: God is in every piece of mud, misery, and human filth - nothing needs to be redeemed. Peirce notices this in one of his reviews for The Nation. ${ }^{15}$ The idea of a unique and yet infinitely dynamic and multifarious substance reverberates in Spinoza's negation of the two Cartesian res. Thinking substance and extended substance are one and the same: Peirce's synechistic principle and the idea expressed by Emerson in "Nature" or in "Oversoul" are, in my view, heirs to this radically anti-dualist and anti-Cartesian assumption, which no other modern author supports so forcefully.

If we are to understand how to "conduct our lives" (to borrow the words of the suitable title of Emerson's volume), Spinoza tells us, we must follow the ontological path of the first two parts. Our conduct of life must be an exercise in the observation of things sub specie aeternitatis: we must learn to understand that there are no separations, distinctions, precise edges between events, but that they all are made up of the same stuff. We must understand that man is nature and nature is infinite things, expressions of divine power; that mind and body, thought and extension, do not belong to opposite domains, but are identical, though perceived according to different attributes (Ethics II, P7). Such an understanding leads to satisfaction and joy, to acquiescence (an important Spinozian and Emersonian term), the achievement of which is the sole purpose of human life. ${ }^{16}$

In the third part, Spinoza develops his anthropology by wisely analyzing human affections. He begins by articulating an idea that, coming from Emerson, will sound familiar to us: everything, as it is, endeavors to persevere in its being (III, P7). This endeavor, this effort, this desire or appetite, this force or drive (translations vary - pragmatically we could add: this habit ${ }^{17}$ ) is called conatus by Spinoza. Man does not control it, but it is a clear expression of human power, that is of his essence.

The endeavour (conatus) by which each thing endeavours to persevere in its being is nothing other than the actual - that is the essence of the thing. Demonstration: So the power, i.e., the endeavour of each thing by which, either alone or with others, it either acts or endeavours to act [...] is nothing other than the given, i.e., the actual essence of the thing" (my emphasis. Ethics, III, P7.)

If man (like every 'mode' of Nature) is characterized by his power to act (potentia agendi), in so far as he has the power to do certain things, then his good and virtue can only be measured against what fulfills this power. The conatus is the first and only foundation of virtue (Ethics IV, P22C.) Ultimately, being virtuous means bringing out one's own talent and capacities. To this we should add that the power in question is an expression, or part, of the power of God, which is to say of Nature (for there is no essential difference between the Substance and its modes.) ${ }^{18}$ Spinoza's Ethics is an ethics of power, of the disposition to act, of the tendency to produce effects and to balance the power of affections. As Deleuze writes, this is no abstruse metaphysics, but a practical philosophy (Deleuze 1981.) The true essence of man - writes Spinoza in Ethics IV, D8 - lies in the strength of this potentia agendi, in so far as "he has the power of doing certain things which can be understood through the laws of his nature alone". Thus, "By virtue and power I understand the same" (IV, D8.) 
In other words, we cannot define and understand man on the basis of what he is, but only on the basis of what he can and cannot do. What matters is how far his efforts, desires, affections, and capacity of producing new effects can go. The conatus is an infinite cupiditas or endeavor, whose directions we cannot predict a priori. It is not an indicative form, but a conditional power. The work of knowledge is to think what increases the power to act of both mind and body.

Like Peirce, Spinoza tells us that well-being is not a state of empty bliss, but the satisfaction that comes from witnessing the growth of concrete reasonableness (CP 1.614, 5.3.) The sage will therefore always be more powerful than the ignorant. Through reason he will be freer and will overcome any form of slavery. Moreover, according to Spinoza, the only human virtue, the only ethics that can be recommended, consists in knowing how to express this conatus satisfactorily or, in Deleuze's words, how to learn not to be alienated by our power.

It follows that we can read Spinoza's ethics as an ethics of power, an ethical exercise concerning our dispositions to act. The word capacity or attitude (aptitudo) is recurrent: for example, in Part II, P13Sc and V, P39. The power expressed by the body in its practices and affections corresponds to the mind's power to perceive and understand things. The potentia agendi becomes potentia intelligendi in IV, P26Dem: 19 "Since this endeavour of the mind by which the mind, in so far as it reasons, endeavors to preserve its being is simply understanding, this endeavors to understand is the primary and sole basis of virtue." This makes it sufficiently clear in my opinion that for Spinoza acting and reasoning are one and the same. Knowledge is the highest, most joyful and most successful form of conatus: an intelligendi conatus. Is this a pragmatist ethics, then? We shall establish this shortly, but we might start by observing that pragmatism, conversely, could be read as a philosophy of power, in the two senses of the word (expressed by the Greek word dynamis): potentiality, attitude, disposition, and ability on the one hand; power, force, and energy on the other. ${ }^{20}$

Allow me, in closing, to offer a historical note on Peirce and Spinoza. I hope to have made it clear that, thanks to the mediation of Emerson (especially the Schellingian Emerson), there are indeed many theoretical links between their views. What Emerson and Peirce share, and what brings these two authors close to Spinoza's panentheism, is not just a synechistic perspective, but an emphasis on the power to act and to produce effects. This may be regarded as the most original element distinguishing these different philosophical traditions.

I have also tried to show that the Spinoza's and Peirce's insistence on the potentia agendi and intelligendi is quite revolutionary in the classical philosophical context. Now, one could object that Peirce makes only a handful of references to this tradition in his work. Yet, the relevance of the passages I shall quote unequivocally reveals the importance of Spinoza in Peirce's thought, at least from 1890 and up to his latest re-examinations of pragmatism. ${ }^{21}$ Indeed, this SpinozianEmersonian tradition acted like a virus: hidden in the folds of Peirce's reflections, it permanently affected their marrow. ${ }^{22}$

Let me direct your attention to some of Peirce's reviews of volumes (published in The Nationover several years) related to the thought of the seventeenth-century philosopher. The short texts are incredibly effective. They document, once again, the stature of a man who had a vast historical, philosophical, scientific, and truly encyclopedic knowledge - above all, a philosopher who thoroughly knew what he was interested in and how to turn this into a living thought, in tune with his general vision of the world.

The first text is the most extraordinary for me; it comes from a review of a new edition of Spinoza's Ethics (edited by W. Hale Wright, Macmillan 1894; Peirce 1894.) Peirce begins by saying that, of course, Spinoza is abstruse; perhaps he did not fully understand the strength of his 
own thought (but then again none of the great philosophers understand themselves), and his geometric apparatus was only "a veil over the living thought", a communicatively useful fiction. However, as if thinking of his own philosophical style, often accused of being disorganized and obscure, Peirce adds:

Crystal clearness, such as we justly require in mathematics, in law, in economics, is in philosophy the characteristic of the second-rates. The reason is that the strongest men are able to seize an all-important conception long before the progress of analysis has rendered it possible to free it from obscurities and difficulties. ${ }^{23}$

Notice the Spinozian distinction between clear and distinct knowledge on the one hand, and vision on the other. Some philosophers, then, have the gift of being able to see and grasp on the fly what is ultimately relevant, before being able to formulate their thoughts as analytical arguments.

In a different review of 1902, manifesting his full appreciation of the Spinozian text, Peirce adds: "his philosophy was deep, out of the common way of thinking" (review of $A$ Study of the Ethics of Spinoza by Harold Joachim, Peirce 1902.) Often we do not understand it because we read it with Cartesian eyes, but Spinoza is valuable precisely for his radical anti-Cartesianism. Curiously, in a subsequent review (Spinoza's Political and Ethical Philosophy by R. Duff; Peirce 1904,) Peirce refers to a Spinozian infection that contaminated Herder, Mendelssohn, Goethe and Schiller - an infection we can trace back to Boehm and forward to Hegel - thus echoing the virus he himself mentions in The Law of Mind.

Finally, the crucial passage:

The commentators have been apt to restrict their studies too much to the one book that is so formal, that they consider Spinoza too exclusively as a metaphysician, and that they have not paid enough attention to his extraordinary approaches toward pragmatism (Peirce 1904.)

Peirce explains that all this had already been quite clear to him even before reading Duff's text, which had simply helped confirm his opinion. In the same review, we further read: "Mr. Duff makes no reference to pragmatism [...] but Spinoza considered philosophy from an intensely practical point of view." If he had lived until the age in which men commonly reach philosophical maturity, he might very likely have "conferred upon philosophy the inestimable advantage of a formulation that vindicates so many judges of common sense and anthropomorphism" (Peirce 1904.)

Consequently, ethics is to be understood as a practical science. Spinoza's aim was not to engage in abstract speculation, but to show human beings how they could lead better lives. To do so, he needed to set out from a metaphysical ontology, yet his goal was an ethical - or, better still, pragmatic - one. Spinoza has taught us that "the substance of what one believes does not consist in any mere sensuous representation, but in how one would be disposed to behave" (ibid., my emphasis. $)^{24}$

After reading these remarkable passages, it is not surprising to find the name of Spinoza in the Collected Papers and related manuscripts, whenever Peirce draws a possible genealogy of pragmatism. ${ }^{25}$ This is the case, for example, in a 1905 letter to Calderoni (CP 8.206): "Of those who have used this way of thinking [pragmaticism] Berkeley is the clearest example, though Locke (especially in the fourth book of his Essay), Spinoza, and Kant may be claimed as adherents of it." ${ }^{26}$ Spinoza is quoted again, in an analogous way, in A Neglected Argument, Additament, 1910 
(CP 6.490): "But although it is 'an old way of thinking,' in the sense that it was practiced by Spinoza, Berkeley, and Kant, I am not aware of its having been definitely formulated, whether as a maxim of logical analysis or otherwise, by anybody before my publication of it in 1878."

There is no doubt, it seems to me, that Peirce regarded Spinoza as someone who was able to appreciate the value of pragmatist principles even in Cartesian and mechanistic times. This is extraordinary if we consider how little of Spinoza's thought was circulating in Peirce's milieu. But, all historical comparisons aside, this conclusion also reveals what Peirce regarded as the correct way of interpreting his pragmatism, namely, as a tendency to articulate the meaning or essence of every entity in light of its power, its capacity to produce new effects and generate habits. It is in such terms that Peirce reformulates the pragmatic maxim in the last stage of his career: ${ }^{27}$ "Consider what effects, that might conceivably have practical bearings - especially in modifying habits or as implying capacities - you conceive the object of your conception to have. Then, your (interpretational) conception of those effects is the whole (meaning of) your conception of the object" (my emphasis, R 322, 1907.) If meaning lies in conceivable practical effects, it is formed entirely by modifying one's habits; hence, it lies in capacities and powers that must find expression in action and can never be exactly defined once for all.

\author{
University of Milan \\ rossella.fabbrichesi@unimi.it
}

\title{
REFERENCES
}

Anderson, Douglas R. (1997). Peirce and Representative Persons. In Philosophy in Experience: American Philosophy in Transition, 77-88. New York: Fordham University Press.

Bowden S., Bignall S. and Patton P. eds. (2015). Deleuze and Pragmatism. New York: Routledge. Bove, Laurent (2002). Introduction à Spinoza B., "Traité Politique." Paris: Librairie Général Française.

(1996). La stratégie du conatus: affirmation et résistance chez Spinoza. Paris: Vrin.

Dea, Shannon (2014). Peirce's and Spinoza's Pragmaticist Metaphysics. Cognitio. Revista de Filosofia, Vol. 15, No.1. 25-35.

Deleuze, Gilles (1968). Spinoza et le problème de l'expression. Paris: Editions de Minuit (transl. 1992. Expressionism in Spinoza. New York: Zone books.)

- (1981) Spinoza. Philosophie pratique. Paris: Editions de Minuit (transl. 1988: Spinoza. Practical philosophy. San Francisco: City Light Books.)

- (2007). Cosa può un corpo?. Verona: Ombre Corte (2nd ed. 2017.)

Dilworth, David A. (2010). Elective Metaphysical Affinities: Emerson's "Natural History of Intellect" and Peirce's Synechism. Cognitio: Revista de Filosofia. Vol. 11, No. 1, (Jan-Jun 2010). 22-47.

Eco, Umberto (1984). Semiotics and the Philosophy of Language. Bloomington: Indiana University Press.

Emerson, Ralph Waldo (1904). The Complete Works. New York and Boston: Houghton, Mifflin. Bartleby.com, 2013.

Fabbrichesi, Rossella (2011). Effects of Truth: the Darwinian Revolution and its Impact on Pragmatism. In Pragmatist Epistemologies, ed. by R. Frega . Lanham (MD): Lexington Books. 153-173.

(2019) Form vs Power. Pragmatism and the Wave of Spinozism. Forthcoming in Cognitio.

Revista de Filosofia. 
Guardiano, Nicholas L. (2016). Aesthetic Transcendentalism in Emerson, Peirce, and NineteenthCentury American Landscape Painting. Lanham MD: Lexington Books.

(2017). Charles S. Peirce's New England Neighbors and Embrace of Transcendentalism. Transactions of the Charles S. Peirce Society: A Quarterly Journal in American Philosophy. No.2. 216-245.

Gueroult, Martial (1930). Spinoza. Tome 1. Dieu. Paris: Aubier.

James, William (1907). The energies of men. "Science", N.S. 25, n. 635. 321-332.

Kaag, John (2013). Returning to the Unformed: Emerson and Peirce on the Law of Mind. Cognitio: Revista de Filosofia. Vol. 14, No. 2, (July-Dec 2013). 189-201.

Kovailanen, Heikki A. and Anderson, Douglas A. R. (2014). Majesty of Truth and the Moral Sentiment. Emerson's and Peirce's Ethico-Ontological Realism. In Realism, Science, and Pragmaticism, ed. by Kenneth Westphal. London-New York: Routledge.

Kruse, Felicia E. (2010). Peirce, God, and the Transcendentalist Virus. Transactions of the Charles S. Peirce Society: A Quarterly Journal in American Philosophy. No. 3. 386-400.

Negri, Toni (1991). Savage Anomaly. The Power of Spinoza's Metaphysics and Politics. Translation by Michael Hardt. Minneapolis, Oxford: University of Minnesota Press.

Peirce, Charles Sanders (1894). Review for The Nation of Benedict de Spinoza's Ethic, 59 (8 Nov 1894.)

(1902). Review for The Nation of Harold H. Joachim's A Study of the Ethics of Spinoza, 75 (10 July 1902).

(1904). Review for The Nation of R. Duff. Spinoza's Political and Ethical Philosophy. New York: MacMillan, 79 (July 21st, 1904).

CP: The Collected Papers. vol. 1-6, ed. by C. Hartshorne, P. Weiss. Cambridge: Harvard University Press, 1931-1935; vol 7-8, ed. by A. Burks. Cambridge: Harvard University Press, 1958. I quote, as usual, with volume and paragraph numbers.

EP: The Essential Peirce. Selected Philosophical Writings. Vol.1, ed. by N. Houser and C. Kloesel,1992; vol. 2, ed. by the Peirce Edition Project. Bloomington: Indiana University Press, 1998. I quote, as usual, with volume and page numbers.

W: Writings of Charles S. Peirce. A Chronological Edition. Volumes 1-8, ed. by the "Peirce Edition Project". Bloomington and Indianapolis: Indiana University Press, 1982-2009. I quote, a usual, with volume and page numbers.

Robin, Richard (1967). Annotated Catalogue of the Papers of Charles S. Peirce. Amherst: The University of Massachusetts Press. Quoted as R followed by number.

Spinoza, Baruch. Ethics (1677). Ed. and transl. by G.H.R. Parkinson. Oxford and New York: Oxford University Press, 2000. I make use of the following abbreviations: the first roman numeral number refers to the Part of the work, the second to $\mathrm{P}$ for Proposition, Dem for Demonstration, Sc for Scholium, D for Definition, C for Corollary.

Vinciguerra, Lorenzo (2005). Spinoza et le signes. La genése de l'imagination. Paris: Vrin.

West, Cornel (1989). The American Evasion of Philosophy: a Genealogy of Pragmatism. University of Wisconsin Press.

Zalamea, Fernando (2017). Peirce's Inversions of the Topological and the Logical. Forgotten Roads of our Contemporary World. In Pragmatism. Some New Ways of Thinking for an Old Name. Monographic Issue. Ed. by R. Fabbrichesi, in collaboration with M. R. Brioschi. Rivista di Storia della Filosofia, No. 3. 415-434.

Zavatta Benedetta (2006). La sfida del carattere. Nietzsche lettore di Emerson. Roma: Editori Riuniti. 
${ }^{1}$ The original, and briefer, version of this paper was delivered in New York, at the Meeting of the Charles Sanders Peirce Society, January 2019.

${ }^{2}$ On the Schelling-Emerson-Peirce link, see Kruse 2010, who presents especially the Peircean formulation "Matter is effete mind" as being purely Schellingian. I would add purely Emersionan, too (see Emerson 1904: "The Natural History of Intellect", Vol. XII:40: "Matter is dead mind."). She quotes a passage from a ms that reads as follows: "My philosophy is Schellingism transformed in the light of modern physics" (Kruse: 2010: 398n3). See also Kaag 2013: 194: "Emerson serves as the intellectual bridge between Peirce and Schelling”, and Guardiano 2016 and 2017.

${ }^{3}$ For more references see Dilworth 2010, Kaag 2013, Kovailanen and Anderson 2014, and Guardiano 2017. This last article and Kaag 2013 note that Peirce lectured on "British Logicians" in 1869-70, Emerson on "The Law of Mind" in 1870 and on "The Natural History of Intellect" in 1870-71 (Emerson 1904, XII). Peirce's 1892 The Law of Mind, then, was clearly inspired by Emerson. In a manuscript quoted in Kovailanen and Anderson 2014, he writes: "I frankly pigeonhole myself as a modified Schellingian, or new England transcendentalist." (R 958)

${ }^{4}$ Guardiano 2017 speaks of "Peirce's New England Neighbors", referring to a sort of proximity that brought Peirce close to Emerson and to his other Bostonian-Concordian fellows, and which endured over the years. In this context Peirce's thought flourished. Guardiano (2017:218) writes that in that neighborhood there was "a synechistic influence of an intellectual culture pervading and broadly affecting the people." These ideas, then, form a sort of continuum of feelings, a "substantial community of transcendentalist grounding" that we can retrace in many Peirce's thoughts. In this article I will argue that the wind of Spinoza blew through the neighborhood of the Concord community, enveloping the Schellingian Emerson and the synechistic Peirce.

${ }^{5}$ Kaag 2013:199 quotes a beautiful passage from Emerson's "Law of Mind": "A man never gets acquainted with himself but is always a surprise and a problem."

${ }^{6}$ In the Preface to Vol.5 of the CP, the editors report this passage from the 1902 Baldwin Dictionary entry "Pragmatic and Pragmatism": "Nevertheless, the maxim has approved itself to the writer, after many years of trial, as of great utility in leading to a relatively high grade of clearness of thought. He would venture to suggest that it should always be put into practice with conscientious thoroughness, but that, when that has been done, and not before, a still higher grade of clearness of thought can be attained by remembering that the only ultimate good which the practical facts to which it directs attention can subserve is to further the development of concrete reasonableness; so that the meaning of the concept does not lie in any individual reactions at all, but in the manner in which those reactions contribute to that development." (CP 5.3.)

7 This appears to be an epigenetic perspective: see Fabbrichesi 2011. In this essay I discuss Chauncey Wright, too. His research has to be borne in mind, since it was so important for Darwin himself. "New uses of some old powers" was his motto, a motto that S.J. Gould has recently rediscovered.

${ }^{8}$ In his crucial introduction to his Pragmatism (EP2: 399,) Peirce refers to Bain's definition of belief: "that upon which a man is prepared to act."

${ }^{9}$ See Zavatta 2006.

${ }^{10}$ This essay is preceded by another fundamental one: "Fate". In the spirit of both Spinoza and Nietzsche, Fate and Power must be considered together. Power is precisely that which leads us, not to oppose fate, but to say 'yes' to it. True freedom is what allows one to accept the "circumstance"; conversely, freedom of the will reflects unavoidable circumstantial necessity 
(Emerson 1904: Vol. VI, Ch.1). We would have to add that in Peirce tychism does not permit a severe form of necessitarianism. Yet, the similarities between Spinoza, Emerson and Peirce seem to me stronger than the differences.

${ }^{11}$ See James, The Energies of Man, for a long-standing tradition in this spirit (James 1907.)

${ }_{12}$ There are, though, more than few references in the Emersonian essays, especially in Nature, Intellect, Quotation and Originality, Character, Plutarch, Inspiration.

${ }^{13}$ Gilles Deleuze actually based his reading of Spinoza on this. See Deleuze 1968, 1981, and, only in Italian, Deleuze 2007. On the link between Deleuze and pragmatism, via Spinoza, see Fabbrichesi 2019. On Deleuze and Pragmatism, in general, see Bowden S., Bignall S. and Patton P. 2015.

${ }^{14}$ On these issues, see Gueroult 1930, Negri 1991, and Deleuze 1968. In "The Natural History of Intellect" (Vol.XII, Ch.1:66) Emerson writes: "It is only the source that we can see - the eternal mind, careless of its channels, omnipotent in itself, and continually ejaculating its torrent into every artery and vein and veinlet of humanity. Wherever there is health, that is, consent to the cause and constitution of the universe, there is perception and power." This seems consistent with Peirce's formulation of continuity, defined as "something whose possibilities of determination no multitude of individuals can exhaust." (CP 6.170)

${ }^{15}$ Review of Harold H. Joachim's A Study of the Ethics of Spinoza, "The Nation" 75 (10 July 1902.)

${ }^{16}$ As regards purpose, an important word in Peirce's vocabulary, we should bear in mind that in What Pragmatism is (1905) Peirce distinguishes himself from James and the other pragmatists by defining his theory as expressing relation to some definite human purpose. "Now quite the most striking feature of the new theory was its recognition of an inseparable connection between rational cognition and rational purpose" (CP 5.412.)

17 This power resembles a habit, as Laurent Bove shows in his introduction to the Tractatus Politicus (2002), by referring to definition XXXII of the Affections (Ethics, Part 3), in which the dispositio is properly assimilated to the conatus ("dispositio seu conatus", a disposition, i.e. endeavor). This passage is illuminating from a pragmatist perspective. In Spinoza, Bove writes, "It is the habit that ensures the continuity of our being. This habit, founding in the living present of its contractions a remembered past and an expected future, establishes time as the very substance of our existence [...] The habit in act explains the existence of all things: it is the figure of the perseverance of being, our habit of living" (Bove 1996:56.)

${ }_{18}$ "The power by which particular things, and consequently a man, preserve their being is the power of God, i.e., of Nature; not in so far as it is infinite, but in so far as it can be explained by actual human essence. So, the power of a man in so far as it is explained through his actual essence, is a part of the infinite power, that is, of the essence, of God, i.e., of Nature" (IV, P4.) He then continues with the interesting statements "The power of God is his essence" (I, P34) and "Nothing exists from whose nature some effect does not follow" (I, P36), followed by the Demonstration "Whatever exists expresses the nature, i.e., the essence, of God in a certain and determinate way. That is, whatever exists expresses in a certain and determinate way the power of God, which is the cause of all things, and so some effect must follow from it."

${ }^{19}$ Note here the following sequence: "The endeavor by which each thing endeavors to persevere in its being is nothing other than the actual essence of the thing (III, P7,) and, as an appetite, is nothing other than the very essence of man, from the the nature of which there necessarily follow those things that contribute to his preservation (see III, P9Sc.) There is no difference between appetite and desire, except that desire is usually related to men in so far as they are conscious of 
their appetite (ibid.). If the essence of reason is nought else but our mind, in so far as it clearly and distinctly understands (IV, P26Dem, and see II, P40Sc2); therefore whatsoever we endeavour in obedience to reason is nothing else but to understand. "Nor shall we endeavour to understand things for the sake of any end. On the contrary, the mind, in so far as it reasons, will be able to conceive as good for itself only that which leads to understanding" (IV, P26Dem.)

${ }^{20}$ Peirce writes that we do not know the "vast ocean of unforeseen consequences which the acceptance of the word is destined to bring about, not merely consequences of knowing but perhaps revolutions of society. One cannot tell what power there may be in a word or a phrase to change the face of the world" (my emphasis. CP 8.186). On energy, see the already quoted James 1910.

${ }^{21}$ There are some scattered quotes about Spinoza in Peirce's earlier works. In 1863 (W1:103) and 1883-4 (W5:493), in a proposed list of the 300 Great Men, but actually they are not very relevant. On these themes see Anderson 1997.

${ }^{22}$ For a very similar interpretation see Guardiano 2017.

${ }^{23}$ I first read this quotation in Zalamea 2017: 419n16, whom I thank for bringing it to my attention. Further on in the review it becomes clear that Peirce was familiar with all the English editions of the Ethics, that he knew the Short Treatise too, and that he was capable of drawing various connections between Spinoza and previous thinkers, including Bruno and Hobbes.

${ }^{24}$ In n. 8 I referred to a nearly literal passage from Pragmatism (1907). Belief is "That upon which a man is prepared to act". Also significant is the following quotation: "judgment, [...] the sole vehicle in which a concept can be conveyed to a person's cognizance or acquaintance, is not a purely representitious event, but involves an act, an exertion of energy, and is liable to real consequences, or effects" (CP 5.547).

${ }^{25}$ To my knowledge, Shannon Dea is the only one to have noticed this important link: see Dea 2014. Yet, in a more semiotic perspective, see Vinciguerra 2005.

${ }^{26}$ Repeated in What Pragmatism is, 1905, CP 5.412, in Pragmatism, 1906, CP 5.11, and in Pragmatism, 1907, EP2:399: "Socrates bathed in these waters. Aristotle rejoices when he can find them. They run, where least one would suspect them, beneath the dry rubbish-heaps of Spinoza." Here Peirce seems scornful. However, as we have seen, a very different opinion emerges from his reviews (it would be interesting, in this regard, to have philologically and chronologically correct editions of relevant manuscripts from the last twenty years of the author's life.)

${ }^{27}$ I thank Mats Bergman for bringing this quotation to my attention. 